\title{
The impact of p16 and HER2 expression on survival in patients with ovarian carcinoma
}

\author{
F. H. SHANDIZ1 ${ }^{1}$ S. KADKHODAYAN ${ }^{2}$, K. GHAFFARZADEGAN ${ }^{3}$, H. ESMAEILY ${ }^{4}$, S. TORABI ${ }^{2}$, S. A. KHALES ${ }^{5, *}$ \\ ${ }^{1}$ Ghaem Hospital, Mashhad University of Medical Sciences, Iran; ${ }^{2}$ Ghaem Hospital, School of Medicine, Mashhad University of Medical Sciences, \\ Iran; ${ }^{3}$ Department of Pathology, Research and Education Department, Razavi Hospital, Mashhad, Iran; ${ }^{4}$ Health Sciences Research Centre, School \\ of Health, Mashhad University of Medical Sciences, Iran; ${ }^{5}$ Department of Modern Sciences and Technologies, School of Medicine, Mashhad \\ University of Medical Sciences, Iran
}

${ }^{*}$ Correspondence: saardalan2007@yahoo.com

Received February 7, 2016 / Accepted June 1, 2016

\begin{abstract}
The purpose of this study was to investigate the impact of p16 and HER2 expression on survival in patients with ovarian carcinoma.

This descriptive-analytic, cross-sectional study, was conducted on 47 paraffin blocks of epithelial ovarian tumors. Suitable slides were prepared to evaluate HER2 and p16 by immunohistochemistry using HercepTest kit (DAKO) and p16INK4A kit (DAKO, code 5334). Clinical information and pathology data were extracted from patients' medical and pathology records. Data entry and analysis was done by SPSS (version 16) software. Chi-square test, Mann-Whitney test, t-test, Kruskal-Wallis test, log rank test and Kaplan-Meier method were used.

The mean age of the patients was 51.6 years (range 19-71 years). The most common histological type of epithelial ovarian cancer was serous adenocarcinoma (68.1\%). P16 expression was detected in 34\% of epithelial ovarian tumors. P16 expression was significantly associated with stage of disease $(P=0.04)$ and overall survival $(P=0.001)$, but HER2 expression was not associated with overall survival, stage of disease and tumor histological type.

Expression of p16 may be used as a prognostic factor of overall survival and stage of disease, while HER2 expression may not be used as a prognostic factor of overall survival.
\end{abstract}

Key words: p16, HER2/neu, immunohistochemistry, epithelial ovarian tumors

Ovarian cancer is the eighth common cancer and the seventh cause of death in women [1]. In Iran, ovarian cancer is the $8^{\text {th }}$ most frequent for incidence [2]. The life-time risk of developing ovarian cancer is estimated to be $1-1.5 \%$. The prevalence of histological types of epithelial ovarian tumors has been reported as follows: serous (75\%), mucinous (20\%), endometrioid $(2 \%)$, clear cell $(<1 \%)$ and undifferentiated carcinomas $(<1 \%)$ [3]. Since symptoms of ovarian cancer in early stages of the disease, are non-specific, most patients are diagnosed in advanced stages [4]. Several biological factors are involved in the disease progression. P16 protein as a tumor-suppressor, plays an important role in cell cycle regulation [5]. Previous studies have demonstrated that high expression of p16 was associated with poor differentiation, poor prognosis, and advanced stage and grade in patients $[6,7]$.
HER2/neu overexpression has been detected in approximately $30 \%$ of breast cancers [8], 25-30\% of ovarian cancers [9], 35-45\% of pancreatic carcinomas [10, 11], and 30-80\% of esophageal adenocarcinoma $[12,13]$, and squamous cell carcinoma [14-16]. Some previous studies have demonstrated that the expression of HER2 is not an important prognostic factor in advanced epithelial ovarian cancer, while the other studies have demonstrated that the overexpression of HER2 is a major prognostic factor in epithelial ovarian cancer [17, 18].

In the present study, we examined the expression of HER2 and 16 by immunohistochemistry (IHC) in epithelial ovarian tumors and their correlation with clinicopathologic variables. The aim of the current study was to investigate the impact of p16 and HER2 expression on survival in patients with ovarian carcinoma. 


\section{Materials and methods}

This descriptive-analytic, cross-sectional study, was conducted on 50 paraffin blocks of epithelial ovarian tumors obtained from the Pathology Department of Ghaem Hospital of Mashhad University of Medical Sciences during 2007 to 2013. Specimens (consisted of 43 malignant tumors (32 serous adenocarcinomas, 7 mucinous adenocarcinomas, 2 endometrioid and 2 clear cell carcinomas), 3 benign tumors ( 1 mucinous and 2 serous cystadenomas) and 4 serous borderline tumors) were selected by the simple sampling method. Benign tumors were excluded from our study. This study was approved by the ethics committee of Mashhad University of Medical Sciences. The suitable block selection criteria include: 1) the maximum tumoral tissue; 2) the minimum extent of necrosis. HercepTest kit (DAKO) which is an immuno-histochemical semi-quantitative assay and P16INK4A kit (DAKO, code 5334) were used to determine the expression of HER2 and p16, respectively. The DAKO HercepTest was conducted exactly according to the manufacturer's instructions. Then the results were divided into two general groups: positive and negative staining. The HER2-positive staining cases were divided into; two groups based on cytoplasmic and membrane staining, three groups of mild, moderate and severe staining based on staining intensity and also four groups of negative (0-10\%), 1+ (11-50\%), 2+ (51-75\%), and 3+ (76-100\%) according to the percentage of cells staining positive based on the distribution of cell membrane staining (Figure 1). The presence or absence of nuclear and cytoplasmic staining was considered for $\mathrm{p} 16$ and the expression of p16 was considered as positive (Figure 2). Clinical information and pathology
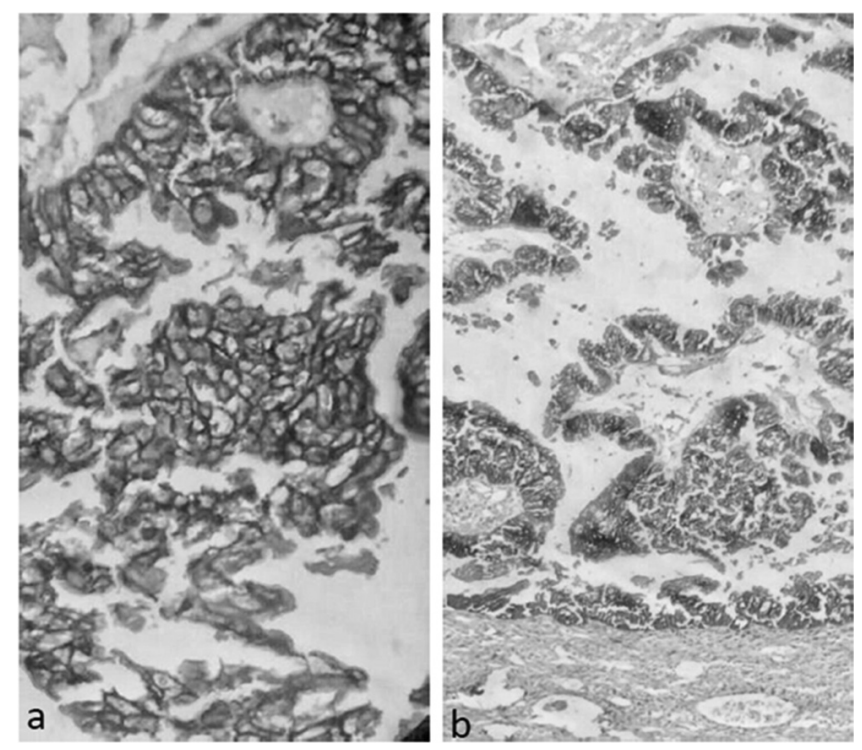

Figure 1. HER2 immunohistochemistry: (a) score $3+, \times 40$, serous adenocarcinoma. (b) score $3+, \times 4$, serous adenocarcinoma. data such as age, histological type, and tumor stage were extracted from patients' medical and pathology records. All data were analyzed by SPSS (version 16) software. Chi-square test, Mann-Whitney test, t-test, Kruskal-Wallis test, log rank test and Kaplan-Meier method were used. A p-value less than 0.05 was considered significant.

\section{Results}

The mean age of the patients was $51.6 \pm 13$ (SD) years (range 19-71 years). The patients were divided into four age groups: $<19,20-40,41-60$ and $61-80$ years. The majority of patients were in the age range of 41-60 years. Among 47 cases, the most common histological type was serous adenocarcinoma (68.1\%, 32 cases), and followed by mucinous adenocarcinoma (14.9\%, 7 cases), serous borderline tumor (8.5\%, 4 cases), endometrioid carcinoma (4.3\%, 2 cases) and clear cell carcinoma (4.3\%, 2 cases). $2.1 \%$ of patients had stage I disease, $27.7 \%$ had stage II disease, $63.8 \%$ had stage III disease and $6.4 \%$ had stage IV disease. Median followup time in patients with ovarian tumors was 27.7 months (range, 6-60 months). During follow-up, 28 patients died. The 24- and 60-month disease-free survival probabilities were $42 \%$ and $17 \%$ and overall survival probabilities were $70 \%$ and $20 \%$, respectively. P16 was positive in $46.9 \%$ of serous adenocarcinomas and $25 \%$ of serous borderline tumors, while it was negative in all mucinous adenocarcinomas, endometrioid and clear cell carcinomas. Overall, p16 expression was detected in $34 \%$ of epithelial ovarian tumors. The relation between p16 expression and stage of disease has been shown in Table 1. P16-positive cases had a significantly higher stage of disease than p16-negative cases $(P=0.04)$. The relation between $\mathrm{p} 16$ expression and disease-free survival and overall survival probabilities (at 24 and 60 months) have been shown in Table 2. P16-positive cases had a significantly lower overall survival probability than p16-negative cases $(P=0.001)$. Furthermore, the disease-free survival probability in p16-positive cases was

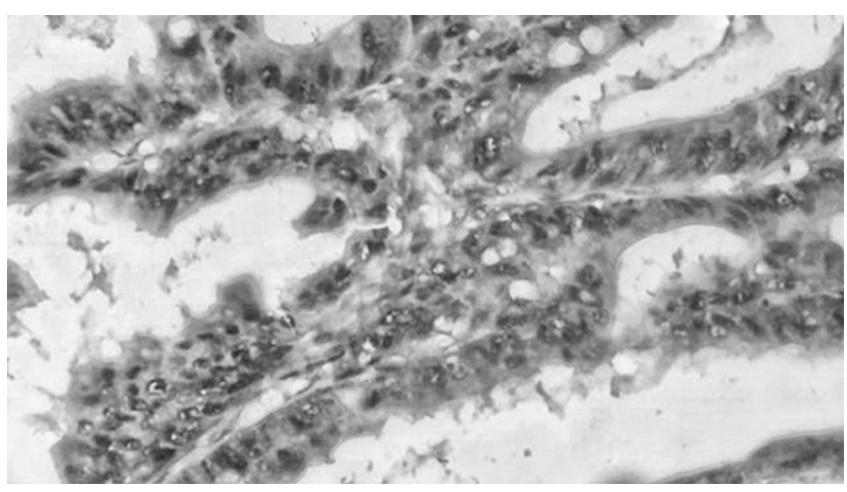

Figure 2. P16 immunohistochemistry, nuclear and cytoplasmic, $\times 40$, serous adenocarcinoma 
Table 1. The relation between p16 expression and stage of tumor (p-value $=0.04$ )

\begin{tabular}{lccc}
\hline & \multicolumn{2}{c}{ p16 expression } & \\
\cline { 2 - 3 } Stage & Positive & Negative & Total \\
\hline I & $0(0.0 \%)$ & $1(3.2 \%)$ & 1 \\
II & $2(12.5 \%)$ & $11(35.5 \%)$ & 13 \\
III & $13(81.3 \%)$ & $17(54.8 \%)$ & 30 \\
IV & $1(6.3 \%)$ & $2(6.5 \%)$ & 3 \\
Total & 16 & 31 & 47 \\
\hline
\end{tabular}

Table 2. The relation between p16 expression and disease-free survival and overall survival probabilities

\begin{tabular}{|c|c|c|c|c|c|}
\hline \multirow{2}{*}{$\begin{array}{l}\text { Follow-up } \\
\text { time } \\
\text { (months) }\end{array}$} & \multicolumn{2}{|c|}{$\begin{array}{l}\text { Overall survival } \\
\text { probability }\end{array}$} & \multicolumn{2}{|c|}{$\begin{array}{l}\text { Disease-free survival } \\
\text { probability }\end{array}$} & \multirow[t]{2}{*}{ p-value } \\
\hline & p16 positive & p16 negative & p16 positive & p16 negative & \\
\hline 24 & $42 \%$ & $86 \%$ & $33 \%$ & $47 \%$ & 0.001 \\
\hline 60 & $8 \%$ & $17 \%$ & $5 \%$ & $22 \%$ & 0.25 \\
\hline
\end{tabular}

lower than p16-negative cases, but the difference was not statistically significant $(P=0.25)$. The relation between cytoplasmic HER2 expression and histological type of tumor has been shown in Table 3. Cytoplasmic HER2 was expressed in $50 \%$ of endometrioid carcinomas, $31.3 \%$ of serous adenocarcinomas and $14.3 \%$ of mucinous adenocarcinomas, while the cytoplasmic HER2 expression was negative in $100 \%$ of clear cell and borderline tumors, that was not statistically significant $(P=0.55)$. The relation between cytoplasmic HER2 expression and stage of disease has been shown in Table 4. There was not a significant relationship between cytoplasmic HER2 expression and stage of disease $(P=0.25)$. Overall survival probability (at 24 and 60 months) in cytoplasmic HER2-positive cases was higher than negative cases $(P=0.16)$, whereas the diseasefree survival probability in cytoplasmic HER2-positive cases was lower than negative cases $(P=0.47)$. There was not a significant relationship between cytoplasmic HER2 expression and overall and disease-free survival. Our results showed that the rate of membrane expression of HER 2 was $29.8 \%$ (score $2+$ and $3+$ considered as positive). Of the 47 cases, $3(6.4 \%)$ were $3+, 11(23.4 \%)$ were $2+, 11$ $(23.4 \%)$ were $1+$ and $22(46.8 \%)$ were 0 . HER 2 membrane staining intensity (score $2+$ and $3+$ ) in borderline tumors, endometrioid carcinomas and serous adenocarcinomas was $75 \%, 50 \%$ and $31.3 \%$, respectively, while it was negative (score 0 and $1+$ ) in all clear cell carcinomas and mucinous adenocarcinomas, that was not statistically significant $(P=$ 0.05). The relation between HER2 membrane expression intensity and stage of disease has been shown in Table 5 . The most HER2 membrane expression intensity was observed in stage III, that was not statistically significant $(P=0.70)$.
Table 3. The relation between cytoplasmic HER2 expression and histological type of tumor $(p$-value $=\mathbf{0 . 5 5})$

\begin{tabular}{lccc}
\hline & \multicolumn{2}{c}{ Cytoplasmic HER2 expression } & \\
\cline { 2 - 3 } Histological type & Positive & Negative & Total \\
\hline serous adenocarcinoma & $10(31.3 \%)$ & $22(68.8 \%)$ & 32 \\
mucinous adenocarcinoma & $1(14.3 \%)$ & $6(85.7 \%)$ & 7 \\
endometrioid carcinoma & $1(50.0 \%)$ & $1(50.0 \%)$ & 2 \\
clear cell carcinoma & $0(0.0 \%)$ & $2(100.0 \%)$ & 2 \\
serous borderline tumor & $0(0.0 \%)$ & $4(100.0 \%)$ & 4 \\
Total & 12 & 35 & 47 \\
\hline
\end{tabular}

Table 4. The relation between cytoplasmic HER2 expression and stage of tumor $(p$-value $=0.25)$

\begin{tabular}{lccc}
\hline & \multicolumn{2}{c}{ Cytoplasmic HER2 expression } & \\
\cline { 2 - 3 } Stage & Positive & Negative & Total \\
\hline I & $0(0.0 \%)$ & $1(2.9 \%)$ & 1 \\
II & $2(16.7 \%)$ & $11(31.4 \%)$ & 13 \\
III & $9(75.0 \%)$ & $21(60.0 \%)$ & 30 \\
IV & $1(8.3 \%)$ & $2(5.7 \%)$ & 3 \\
Total & 12 & 35 & 47 \\
\hline
\end{tabular}

Table 5. The relation between HER2 membrane expression intensity and stage of tumor $(p$-value $=0.70)$

\begin{tabular}{lccccc}
\hline & \multicolumn{4}{c}{ HER2 } & \multicolumn{3}{c}{ membrane expression intensity } & \\
\cline { 2 - 5 } Stage & 0 & $1+$ & $2+$ & $3+$ & Total \\
\hline I & $1(100.0 \%)$ & $0(0.0 \%)$ & $0(0.0 \%)$ & $0(0.0 \%)$ & 1 \\
II & $6(46.2 \%)$ & $4(30.8 \%)$ & $3(23.1 \%)$ & $0(0.0 \%)$ & 13 \\
III & $13(43.3 \%)$ & $7(23.3 \%)$ & $7(23.3 \%)$ & $3(10.0 \%)$ & 30 \\
IV & $2(66.7 \%)$ & $0(0.0 \%)$ & $1(33.3 \%)$ & $0(0.0 \%)$ & 3 \\
Total & 22 & 11 & 11 & 3 & 47 \\
\hline
\end{tabular}

${ }^{* *} 0$, no staining or membrane staining in fewer than $10 \%$ of tumor cells (negative); $1+$, faint or barely perceptible incomplete membrane staining in more than $10 \%$ of tumor cells (negative); $2+$, weak to moderately complete membrane staining in more than $10 \%$ of tumor cells (weakly positive); $3+$, strong, complete membrane staining in more than $10 \%$ of tumor cells (strongly positive).

The relation between HER2 membrane staining distribution and histological type of tumor has been shown in Table 6 . The most HER2 membrane staining distribution (positive staining in $>50 \%$ of cells) was observed in serous borderline tumor (75\%), endometrioid carcinoma (50\%) and serous adenocarcinoma (31.3\%), while it was in the range of $0-10 \%$ (negative) in clear-cell carcinoma, that was not statistically significant $(P=0.06)$. Overall survival probability (at 24 and 60 months) in membrane HER2-positive cases was lower than negative cases $(P=0.07)$, furthermore the disease-free survival probability (at 24 and 60 months) in membrane HER2-positive cases was also lower than negative cases, that was not statistically significant $(P=0.64)$ (Table 7). 
Table 6. The relation between HER2 membrane staining distribution and histological type of tumor $(p$-value=0.06)

\begin{tabular}{|c|c|c|c|c|c|}
\hline \multirow[b]{2}{*}{ Histological type } & \multicolumn{4}{|c|}{ HER2 membrane staining distribution } & \multirow[b]{2}{*}{ Total } \\
\hline & $0-10 \%$ & $11-50 \%$ & $51-75 \%$ & $76-100 \%$ & \\
\hline serous adenocarcinoma & $14(43.8 \%)$ & $8(25.0 \%)$ & $6(18.8 \%)$ & $4(12.5 \%)$ & 32 \\
\hline mucinous adenocarcinoma & $5(71.4 \%)$ & $1(14.3 \%)$ & $1(14.3 \%)$ & $0(0.0 \%)$ & 7 \\
\hline endometrioid carcinoma & $1(50.0 \%)$ & $0(0.0 \%)$ & $1(50.0 \%)$ & $0(0.0 \%)$ & 2 \\
\hline clear cell carcinoma & $2(100.0 \%)$ & $0(0.0 \%)$ & $0(0.0 \%)$ & $0(0.0 \%)$ & 2 \\
\hline serous borderline tumor & $0(0.0 \%)$ & $1(25.0 \%)$ & $1(25.0 \%)$ & $2(50.0 \%)$ & 4 \\
\hline Total & 22 & 10 & 9 & 6 & 47 \\
\hline
\end{tabular}

\section{Discussion}

The purpose of this study was to investigate the impact of p16 and HER2 expression on survival in patients with ovarian carcinoma. In previous studies, high expression of p16 was associated with poor differentiation, poor prognosis, and advanced stage and grade in patients $[6,7]$. The expression of p16 in ovarian carcinoma has been reported different in various studies. In our study, p16 expression was detected in $34 \%$ of epithelial ovarian tumors. P16 was positive in $46.9 \%$ of serous adenocarcinomas and $25 \%$ of serous borderline tumors, while it was negative in all mucinous adenocarcinomas, endometrioid and clear cell carcinomas. In the study by Khouja et al, high level of p16 was expressed in $31 \%$ of advanced ovarian carcinoma [7]. In the study by Dong et al, only $11 \%$ of malignant ovarian tumors were p 16 negative and the benign ovarian tumors showed no expression of p16 [6]. In our study, p16-positive cases had a significantly higher stage of disease than p16-negative cases. Dong et al. (1997) studied 190 epithelial ovarian tumors, and demonstrated that high number of p16-positive tumor cells was associated with advanced stage [6]. In our study, p16-positive cases had a significantly lower overall survival probability (at 24 and 60 months) than p16-negative cases. The disease-free survival probability (at 24 and 60 months) in p16-positive cases was lower than p16-negative cases. A significant influence of p16 expression on overall survival was not confirmed by MildeLangosch et al [19].

HER2/neu overexpression has been reported in several human cancers, such as breast, ovary, stomach, esophagus, endometrium, pancreas, colon, bladder and lung [20-28]. In ovarian cancer, the percentage of HER2-positive tumors has been reported varied in various studies [29-36]. In epithelial ovarian cancer, the prognostic value of HER2/neu overexpression remains controversial [37-41]. Rubin et al. had reported that the expression of HER2 is not an important prognostic factor in advanced epithelial ovarian cancer [18], while Coronado et al. demonstrated that the overexpression of HER2/neu is a major prognostic factor in epithelial ovarian cancer and it is an independent prognostic factor for overall survival [17]. In Verri et al.' s study no significant correlation was detected between HER2 membrane staining intensity and pathological and clinical features, but a significant correlation between
Table 7. The relation between membrane HER 2 expression and disease-free survival and overall survival probabilities

\begin{tabular}{|c|c|c|c|c|c|}
\hline \multirow{2}{*}{$\begin{array}{l}\text { Follow-up } \\
\text { time } \\
\text { (months) }\end{array}$} & \multicolumn{2}{|c|}{$\begin{array}{l}\text { Overall survival } \\
\text { probability }\end{array}$} & \multicolumn{2}{|c|}{$\begin{array}{c}\text { Disease-free } \\
\text { survival probability }\end{array}$} & \multirow[t]{2}{*}{$\mathrm{p}$-value } \\
\hline & $\begin{array}{l}\text { HER-2 } \\
\text { positive }\end{array}$ & $\begin{array}{l}\text { HER-2 } \\
\text { negative }\end{array}$ & $\begin{array}{l}\text { HER-2 } \\
\text { positive }\end{array}$ & $\begin{array}{l}\text { HER-2 } \\
\text { negative }\end{array}$ & \\
\hline 24 & $57 \%$ & $88 \%$ & $40 \%$ & $45 \%$ & 0.07 \\
\hline 60 & $25 \%$ & $29 \%$ & $13 \%$ & $22 \%$ & 0.64 \\
\hline
\end{tabular}

overexpression of HER2 with an increased risk of death and progression was observed especially in women with stage I and II ovarian cancer [36]. In our study, there was no significant relationship between cytoplasmic HER2 expression and stage of disease, overall and disease-free survival. The rate of membrane expression of HER2 was 29.8\% (score 2+ and $3+$ considered as positive). HER 2 membrane staining intensity (score 2+ and 3+) in borderline tumors, endometrioid carcinomas and serous adenocarcinomas was $75 \%, 50 \%$ and $31.3 \%$, respectively, while it was negative (score 0 and $1+$ ) in all clear cell carcinomas and mucinous adenocarcinomas. The most HER2 membrane staining distribution (positive staining in $>50 \%$ of cells) was observed in serous borderline tumor, endometrioid carcinoma and serous adenocarcinoma, respectively. Overall survival probability and disease-free survival probability (at 24 and 60 months) in membrane HER2-positive cases were lower than negative cases. The study of Coronado et al. indicated that HER2 was expressed in $24.2 \%$ of ovarian tumors and its expression was correlated with clear cell and undifferentiated types [17]. In the study by Wu et al, HER 2 was expressed in $6.7 \%$ of ovarian tumors and its expression was restricted to ovarian carcinoma and was not encountered in borderline tumors [42]. Eltabbakh et al. have detected HER2 overexpression in $20-25 \%$ of borderline tumors (especially in seromucinous) [43].

In our study, the most HER2 membrane expression intensity was observed in stage III. Riener et al. reported that overexpression of HER2 is significantly associated with the stage of tumor [44]. Coronado et al. reported overexpression of HER2 was related to advanced-stage [17]. Eltabbakh et al. demonstrated that overexpression of HER2 was significantly higher in stage III than stage I [43]. 


\section{Conclusion}

In conclusion, according to the results, p16 expression may be used as a prognostic factor of overall survival and stage of disease, while HER2 expression may not be used as a prognostic factor of overall survival.

Acknowledgments: The authors gratefully acknowledge the efforts and cooperation of the Pathology Department of Ghaem Hospital.

\section{References}

[1] WHO, IARC GLOBOCAN, Cancer Incidence and Mortality Worldwide in 2008 at http: //globocan.iarc.fr/.

[2] AKBARI ME, ABACHIZADEH K, KHAYAMZADEH M, TABATABAEE M, ESNAASHARI F, et al. Iran Cancer Report. Tehran, Iran: CRC. SBMU; 2008.

[3] BEREK JS. Berek \& Novak's Gynecology, 14th Edition. Lippincott Williams \& Wilkins, ed; 2006.

[4] ROSSING MA, WICKLUND KG, CUSHING-HAUGEN KL, WEISS NS. Predictive value of symptoms for early detection of ovarian cancer. J Natl Cancer Inst 2010; 102: 222-229. http:// dx.doi.org/10.1093/jnci/djp500

[5] FELIX K, PETER S, HENNING S. Drug Delivery in Oncology: From Basic Research to Cancer Therapy. illustrated ed: John Wiley \& Sons, 2011.

[6] DONG Y, WALSH MD, MCGUCKIN MA, GABRIELLI BG, CUMMINGS MC, et al. Increased expression of cyclin-dependent kinase inhibitor 2 (CDKN2A) gene product P16INK4A in ovarian cancer is associated with progression and unfavourable prognosis. Int J Cancer 1997; 74: 57-63. http://dx.doi.org/10.1002/(SICI)1097-0215(19970220)74:1<57::AID-IJC10>3.0.CO;2-F

[7] KHOUJA MH, BAEKELANDT M, NESLAND JM, HOLM R. The clinical importance of Ki-67, p16, p14, and p57 expression in patients with advanced ovarian carcinoma. Int J Gynecol Pathol 2007; 26: 418-425. http://dx.doi.org/10.1097/ pgp.0b013e $31804216 \mathrm{a} 0$

[8] REVILLION F, BONNETERRE J, PEYRAT JP. ERBB2 oncogene in human breast cancer and its clinical significance. Eur J Cancer 1998; 34: 791-808. http://dx.doi.org/10.1016/ S0959-8049(97)10157-5

[9] LIN CK, LIN WL, CHEN FL, LEE MY, KUO JF, et al. Assessing the impact of polysomy-17 on HER2 status and the correlations of HER2 status with prognostic variables (ER, PR, p53, Ki-67) in epithelial ovarian cancer: a tissue microarray study using immunohistochemistry and fluorescent in situ hybridization. Int J Gynecol Pathol 2011; 30: 372-379. http:// dx.doi.org/10.1097/PGP.0b013e31820c9ff3

[10] STOECKLEIN NH, LUEBKE AM, ERBERSDOBLER A, KNOEFEL WT, SCHRAUT W, et al. Copy number of chromosome 17 but not HER2 amplification predicts clinical outcome of patients with pancreatic ductal adenocarcinoma. J Clin Oncol 2004; 22: 4737-4745. http://dx.doi.org/10.1200/ ICO.2004.05.142
[11] YAMANAKA Y, FRIESS H, KOBRIN MS, BUCHLER M, KUNZ J, et al. Overexpression of HER2/neu oncogene in human pancreatic carcinoma. Hum Pathol 1993; 24: 1127-1134. http://dx.doi.org/10.1016/0046-8177(93)90194-L

[12] SAFRAN H, DIPETRILLO T, AKERMAN P, NG T, EVANS $\mathrm{D}$, et al. Phase I/II study of trastuzumab, paclitaxel, cisplatin and radiation for locally advanced, HER2 overexpressing, esophageal adenocarcinoma. Int J Radiat Oncol Biol Phys 2007; 67: 405-409. http://dx.doi.org/10.1016/j.ijrobp.2006.08.076

[13] YENTZ S, WANG TD. Molecular imaging for guiding oncologic prognosis and therapy in esophageal adenocarcinoma. Hosp Pract (1995). 2011; 39: 97-106. http://dx.doi. org/10.3810/hp.2011.04.399

[14] SZENTIRMAY Z. [Effect of learning about the human genome on the development of pathology]. Orv Hetil 2003; 144: 2499-2508.

[15] WEI Q, CHEN L, SHENG L, NORDGREN H, WESTER K, et al. EGFR, HER2 and HER3 expression in esophageal primary tumours and corresponding metastases. Int J Oncol 2007; 31: 493-9. http://dx.doi.org/10.3892/ijo.31.3.493

[16] ZHAN N, DONG WG, TANG YF, WANG ZS, XIONG CL. Analysis of HER2 gene amplification and protein expression in esophageal squamous cell carcinoma. Med Oncol 2012; 29: 933-940. http://dx.doi.org/10.1007/s12032-011-9850-y

[17] CORONADO MARTIN PJ, FASERO LAIZ M, GARCIA SANTOS J, RAMIREZ MENA M, VIDART ARAGON JA. Overexpression and prognostic value of $\mathrm{p} 53$ and HER2/neu proteins in benign ovarian tissue and in ovarian cancer. Med Clin (Barc) 2007; 128: 1-6.

[18] RUBIN SC, FINSTAD CL, WONG GY, ALMADRONES L, PLANTE M, et al. Prognostic significance of HER-2/neu expression in advanced epithelial ovarian cancer: a multivariate analysis. Am J Obstet Gynecol 1993; 168: 162-169. http:// dx.doi.org/10.1016/S0002-9378(12)90907-2

[19] MILDE-LANGOSCH K, HAGEN M, BAMBERGER AM, LONING T. Expression and prognostic value of the cell-cycle regulatory proteins, Rb, p16MTS1, p21WAF1, p27KIP1, cyclin E, and cyclin D2, in ovarian cancer. Int J Gynecol Pathol 2003; 22: 168-174. http://dx.doi.org/10.1097/00004347-200304000$\underline{00009}$

[20] AL-KASSPOOLES M, MOORE JH, ORRINGER MB, BEER DG. Amplification and over-expression of the EGFR and erbB-2 genes in human esophageal adenocarcinomas. Int J Cancer 1993; 54: 213-219. http://dx.doi.org/10.1002/ ijc. 2910540209

[21] BERNS EM, KLIJN JG, VAN STAVEREN IL, PORTENGEN $\mathrm{H}$, NOORDEGRAAF E, et al. Prevalence of amplification of the oncogenes c-myc, HER2/neu, and int-2 in one thousand human breast tumours: correlation with steroid receptors. Eur J Cancer 1992; 28: 697-700. http://dx.doi.org/10.1016/ S0959-8049(05)80129-7

[22] D'EMILIA J, BULOVAS K, D’ERCOLE K, WOLF B, STEELE G, JR., et al. Expression of the c-erbB-2 gene product (p185) at different stages of neoplastic progression in the colon. Oncogene 1989; 4: 1233-1239.

[23] JAEHNE J, URMACHER C, THALER HT, FRIEDLANDERKLAR H, CORDON-CARDO C, et al. Expression of Her2/neu 
oncogene product p185 in correlation to clinicopathological and prognostic factors of gastric carcinoma. J Cancer Res Clin Oncol 1992; 118: 474-479. http://dx.doi.org/10.1007/ $\underline{\mathrm{BF} 01629433}$

[24] KERN JA, SCHWARTZ DA, NORDBERG JE, WEINER DB, GREENE MI, et al. p185neu expression in human lung adenocarcinomas predicts shortened survival. Cancer Res 1990; 50: 5184-5187.

[25] LEI S, APPERT HE, NAKATA B, DOMENICO DR, KIM K, et al. Overexpression of HER2/neu oncogene in pancreatic cancer correlates with shortened survival. Int J Pancreatol 1995; 17: 15-21.

[26] NEAL DE, MARSH C, BENNETT MK, ABEL PD, HALL $\mathrm{RR}$, et al. Epidermal-growth-factor receptors in human bladder cancer: comparison of invasive and superficial tumours. Lancet 1985; 1: 366-368. http://dx.doi.org/10.1016/S01406736(85)91386-8

[27] ROLITSKY CD, THEIL KS, MCGAUGHY VR, COPELAND LJ, NIEMANN TH. HER-2/neu amplification and overexpression in endometrial carcinoma. Int J Gynecol Pathol 1999; 18: 138-143. http://dx.doi.org/10.1097/00004347-199904000$\underline{00007}$

[28] SLAMON DJ, GODOLPHIN W, JONES LA, HOLT JA, WONG SG, et al. Studies of the HER-2/neu proto-oncogene in human breast and ovarian cancer. Science 1989; 244: 707-712. http://dx.doi.org/10.1126/science.2470152

[29] CHAY WY, CHEW SH, ONG WS, BUSMANIS I, LI X, et al. HER2 amplification and clinicopathological characteristics in a large Asian cohort of rare mucinous ovarian cancer. PLoS One 2013; 8: e61565. http://dx.doi.org/10.1371/journal. pone.0061565

[30] FUJIMURA M, KATSUMATA N, TSUDA H, UCHI N, MIYAZAKI S, et al. HER2 is frequently over-expressed in ovarian clear cell adenocarcinoma: possible novel treatment modality using recombinant monoclonal antibody against HER2, trastuzumab. Jpn J Cancer Res 2002; 93: 1250-1257. http://dx.doi.org/10.1111/j.1349-7006.2002.tb01231.x

[31] HAN CP, HSU JD, YAO CC, LEE MY, RUAN A, et al. HER2 gene amplification in primary mucinous ovarian cancer: a potential therapeutic target. Histopathology 2010; 57: 763-764. http://dx.doi.org/10.1111/j.1365-2559.2010.03689.x

[32] MCCAUGHAN H, UM I, LANGDON SP, HARRISON DJ, FARATIAN D. HER2 expression in ovarian carcinoma: caution and complexity in biomarker analysis. J Clin Pathol 2012; 65: 670-671; author reply 1-2. http://dx.doi.org/10.1136/ jclinpath-2011-200616

[33] RAMIERI MT, MURARI R, BOTTI C, PICA E, ZOTTI G, et al. Detection of HER2 amplification using the SISH technique in breast, colon, prostate, lung and ovarian carcinoma. Anticancer Res 2010; 30: 1287-1292.

[34] STEFFENSEN KD, WALDSTROM M, JEPPESEN U, JAKOBSEN E, BRANDSLUND I, et al. The prognostic importance of cyclooxygenase 2 and HER2 expression in epithelial ovarian cancer. Int J Gynecol Cancer 2007; 17: 798-807. http://dx.doi. org/10.1111/j.1525-1438.2006.00855.x

[35] TUEFFERD M, COUTURIER J, PENAULT-LLORCA F, VINCENT-SALOMON A, BROET P, et al. HER2 status in ovarian carcinomas: a multicenter GINECO study of 320 patients. PLoS One 2007; 2: e1138. http://dx.doi.org/10.1371/ journal.pone.0001138

[36] VERRI E, GUGLIELMINI P, PUNTONI M, PERDELLI L, PAPADIA A, et al. HER2/neu oncoprotein overexpression in epithelial ovarian cancer: evaluation of its prevalence and prognostic significance. Clinical study. Oncology 2005; 68: 154-161. http://dx.doi.org/10.1159/000086958

[37] CAMILLERI-BROET S, HARDY-BESSARD AC, LE TOURNEAU A, PARAISO D, LEVREL O, et al. HER-2 overexpression is an independent marker of poor prognosis of advanced primary ovarian carcinoma: a multicenter study of the GINECO group. Ann Oncol 2004; 15: 104-112. http:// dx.doi.org/10.1093/annonc/mdh021

[38] FAJAC A, BENARD J, LHOMME C, REY A, DUVILLARD $\mathrm{P}$, et al. c-erbB2 gene amplification and protein expression in ovarian epithelial tumors: evaluation of their respective prognostic significance by multivariate analysis. Int J Cancer 1995; 64: 146-151. http://dx.doi.org/10.1002/ijc.2910640213

[39] FELIP E, DEL CAMPO JM, RUBIO D, VIDAL MT, COLOMER R, et al. Overexpression of c-erbB-2 in epithelial ovarian cancer. Prognostic value and relationship with response to chemotherapy. Cancer 1995; 75: 2147-2152. http:// dx.doi.org/10.1002/1097-0142(19950415)75:8<2147::AIDCNCR2820750818>3.0.CO;2-8

[40] MEDEN H, MARX D, RATH W, KRON M, FATTAHIMEIBODI A, et al. Overexpression of the oncogene c-erb B2 in primary ovarian cancer: evaluation of the prognostic value in a Cox proportional hazards multiple regression. Int J Gynecol Pathol 1994; 13: 45-53. http://dx.doi.org/10.1097/00004347199401000-00006

[41] MEDL M, SEVELDA P, CZERWENKA K, DOBIANER K, HANAK $H$, et al. DNA amplification of HER-2/neu and INT-2 oncogenes in epithelial ovarian cancer. Gynecol Oncol 1995; 59: 321-326. http://dx.doi.org/10.1006/gyno.1995.9969

[42] WU Y, SOSLOW RA, MARSHALL DS, LEITAO M, CHEN B. Her-2/neu expression and amplification in early stage ovarian surface epithelial neoplasms. Gynecol Oncol 2004; 95: 570-575. http://dx.doi.org/10.1016/j.ygyno.2004.08.043

[43] ELTABBAKH GH, BELINSON JL, KENNEDY AW, BISCOTTI CV, CASEY G, et al. p53 and HER-2/neu overexpression in ovarian borderline tumors. Gynecol Oncol 1997; 65: 218-224. http://dx.doi.org/10.1006/gyno.1997.4661

[44] RIENER EK, ARNOLD N, KOMMOSS F, LAUINGER S, PFISTERER J. The prognostic and predictive value of immunohistochemically detected HER-2/neu overexpression in 361 patients with ovarian cancer: a multicenter study. Gynecol Oncol 2004; 95: 89-94. http://dx.doi.org/10.1016/j. ygyno.2004.06.048 